\title{
Biomedical system to evaluate pulmonary function in patients with post-stroke hemiparesis
}

\author{
Sistema biomédico para avaliação da função respiratória de pacientes \\ hemiparéticos por acidente vascular encefálico
}

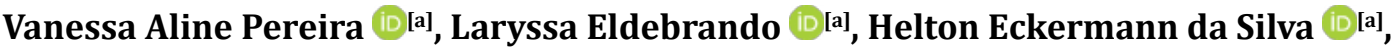

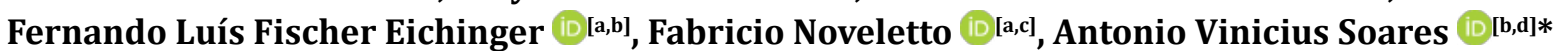

[a] Faculdade Guilherme Guimbala, Joinville, SC, Brazil

[b] Universidade da Região de Joinville (Univille), Joinville, SC, Brazil

[c] Universidade do Estado de Santa Catarina (Udesc), Joinville, SC, Brazil

[d] Faculdade IELUSC, Joinville, SC, Brazil

\begin{abstract}
Introduction: Stroke is a neurological disorder considered the second major cause of death worldwide, leading to severe respiratory dysfunctions, evident in reduced respiratory muscle strength and the presence of muscle imbalances that directly affect the pulmonary mechanics of these patients. Objective: Evaluate the possible metric properties of a biomedical system, the IBI. Method: the study was conducted with 25 hemiparetic stroke patients of both sexes, using a manovacuometer, peak flow, and SG IBI for respiratory measurements. Results: Moderate to strong correlations were observed between the IBI biomedical system and peak flow and manovacuometer measurements, which were smaller than the predicted values. Conclusion: The results suggest that the IBI biomedical system is potentially valid for pulmonary function
\end{abstract}

*VAP: undergrad, email: vanessaalinep@gmail.com LE: undergrad, email: laryssaeldi@gmail.com HES: MS, email: heltonfisiot@yahoo.com.br FLFE: MS, email: fernando_lfe@hotmail.com FN: PhD, email: bitbasico@gmail.com AVS: PhD, email: provinicius.soares@gmail.com 
measurement, sensitive to air flow variations and generates maximum respiratory pressure. As such, it is an important resource for prescribing intensity and controlling progression in pulmonary rehabilitation.

Keywords: Video Games. Pulmonary Function Tests. Hemiparesis. Stroke.

\section{Resumo}

Introdução: O Acidente Vascular Encefálico (AVE) é um distúrbio neurológico que ocupa o segundo lugar entre os eventos que causam os maiores índices de mortalidade mundialmente, ocasionando diversas disfunções respiratórias, evidenciadas pela redução da força muscular respiratória e presença de desequilíbrios musculares que afetam diretamente a mecânica pulmonar desses pacientes. Objetivo: Avaliar as possíveis propriedades métricas do Sistema Biomédico, I blue It (IBI). Método: 0 estudo foi realizado com 25 participantes voluntários de ambos os sexos hemiparéticos por AVE, sendo realizado para a mensuração respiratória: Manovacuômetro, Peak Flow e o IBI. Resultados: Moderadas a fortes correlações foram observadas entre o IBI e as medidas no Peak Flow e Manovacuômetro, sendo tais medidas menores que os valores preditos. Conclusão: Os resultados encontrados nesta pesquisa sugerem que o IBI possui potencial validade de mensuração da função respiratória, e é sensível as variações de fluxo aéreo e a capacidade de gerar pressões máximas respiratórias, portanto sendo importante recurso de prescrição de intensidade e controle da progressão em reabilitação respiratória.

Palavras-chave: Jogos de Vídeo. Testes de Função Respiratória. Hemiparesia. Acidente Vascular Cerebral.

\section{Introduction}

Stroke, a neurological disorder that has major social impacts [1], results from changes in blood irrigation, and can be ischemic, via occlusion of a cerebral artery, or hemorrhagic, due to vascular rupture (aneurism and arteriovenous malformations), the latter being the most severe and the former the most frequent $[2,3]$. It is the second leading cause of death and the leading cause of physical and mental disability worldwide, resulting in dependence in the activities of daily living (ADL) due to trunk muscle weakness and physical deconditioning $[4,5]$.

Epidemiological data indicate that 16.9 million people suffer a stroke every year, representing a global rate of 258 cases per 100,000 inhabitants [6].

The clinical picture of stroke is characterized by hemiplegia and hemiparesis, defined as the total or partial loss of movements in the hemibody contralateral to the injury. Changes in the respiratory system include altered breathing pattern, reduced ventilatory function, respiratory muscle weakness and diaphragmatic hypofunction on the paretic side [7].

Respiratory muscle function in hemiparetic patients decreases by $50 \%$, when compared to healthy individuals [8]. Hemiparesis causes muscle imbalance and a decline in abdominal muscle activation, changing the position of the rib cage, thereby decreasing respiratory muscle strength [7].

Changes in thoracic and pulmonary complacency, ventilatory pattern and pulmonary volumes compromise the protective mechanisms of the respiratory system, such as cough, which depends on air flow and high airway pressure to be effective and may be negatively affected in some stroke cases [9-11], leading to respiratory complications [12].

Despite being widely acknowledged and described in the literature, pulmonary rehabilitation in stroke is not a routine strategy, especially in the outpatient phase, given that it is not prioritized in functional assessment $[13,14]$. Cough efficacy and respiratory muscle strength should be assessed in physiotherapy, using peak flow and maximum static respiratory pressures, given the risk of aspiration due to dysphagia and inadequate airway protection by coughing [15].

New technological resources have been proposed to evaluate and train respiratory muscles, such as Virtual Reality (VR) and Serious Games (SGs). Studies that have used these technologies are relatively recent. Lange et al. [16] developed a set of six minigames called Breathe as a therapeutic resource for pulmonary rehabilitation, using a commercial spirometer connected to software 
that measures the rate and amount of air over a certain time, that is, captures respiratory data of the participant's performance. Another example is Wind Runner [17], a game developed for children with asthma aimed at measuring peak flow (PF) daily. These resources enable greater training intensity and provide visual and auditory biofeedback, making them an important ally of health professionals [8].

In recent years, assessments based on SGs have been gaining popularity as an alternative therapy, due to their low cost, accessibility and portability [18].

The aim of the present study was to assess the possible metric properties of the IBI, a biomedical system [19]. This resource was developed for two purposes: as an assessment device and a training module in the form of a Serious Game. The emphasis at this stage of the research was to evaluate the system as a potential measuring instrument. Thus, the IBI was used in the respiratory assessment of patients with post-stroke hemiparesis.

\section{Method}

A preliminary descriptive correlational study was conducted to validate the IBI biomedical system proposed. Thus, the measures in this system were correlated with widely used conventional instruments, such as Peak Flow and a manovacuometer.

A total of 40 patients of both sexes with poststroke hemiparesis, from the Neurology Outpatient Facility belonging to the Guilherme Guimbala Faculty, located in Joinville, Santa Catarina (SC) state, took part in the study between June and August 2019. After being informed of the procedures, all the participants gave their written informed consent.

Inclusion criteria were clinically stable hemiparetic stroke patients; aged 18 years or older; having manifested only one event; agreeing and showing interest in taking part in the project from start to finish and giving written informed consent. Exclusion criteria were severe visual and/or auditory impairment; uncooperative patients and/or with severe cognitive impairment assessment using the Mini Mental State Examination; incapable of bipedalism (assistive devices such as crutches, walking sticks or walkers could be used); those undergoing pulmonary rehabilitation, tracheostomized or requiring oxygen support; those unable to seal their lips around the mouthpieces in the pulmonary function tests and individuals who could not tolerate using nose clips during the tests.

The study procedures are in line with National Health Council resolution 466/12 and were approved by the Research Ethics Committee of Dona Helena Hospital in Joinville (Santa Catarina), Brazil, under protocol number 12826219.6.0000.8062.

The data were analyzed in Graph Pad Prism 6 software. Descriptive statistics (mean, standard deviation, minimum and maximum values), the ShapiroWilk test (data normality), student's t-test for independent samples (comparison between measured and expected values) and Pearson's correlation coefficient (correlation between the measures obtained by IBI and the other tests performed) were used. A 5\% significance level was set for all the tests.

\section{Measuring instruments and procedures}

All the participants were interviewed using a registration form prepared by the researchers to collect identification and sociodemographic data, clinical information, anthropometric data and the Mini Mental State Examination in order to confirm their ability to understand the tests proposed. Next, respiratory measures were taken using volitional tests, applying the IBI biomedical system, peak flow meter and manovacuometer.

\section{IBI Biomedical System}

The IBI tells the story of the voyage of a dolphin named Blue, whose goal is to reach targets and avoid obstacles. The character is controlled by respiratory incursions (inspiration and expiration), characterizing the game itself as respiratory training. Inspiration corresponds to leaps of the dolphin and expiration to dives, with players advancing to the next stages based on their performance.

According to Santos etal. [19], the IBI used ARDUINO NANO R3 hardware because of its compact size and reasonable cost. In relation to the pressure sensor, the MPX5010DP was used to obtain sufficient data to measure peak respiratory flow and the results were entered into a computer via USB. Pneumotachography is the standard used to measure flow and respiratory volume. In the IBI game, the pneumotachograph (called pitaco) consisted of a pipe, lid (perforated), PVC reducers, pressure sensor (MPX5010DP), microtubing, 
microcontroller (ARDUINO NANO R3), USB cable and disposable bacteriological filter coupled to the mouthpiece in order to protect the participant from possible contamination.

The IBI also has minigames that propose specific breathing tasks and provide metrics on player performance [19]. The minigame used in the study to measure PEF was "Bolo" (cake), where the image of a cake with three burning candles is presented, with the user blowing them out to promote the greatest expiratory effort possible in the pitaco. This variable was denominated expiratory IBI (E-IBI). The other minigame, called "copo d'água" (glass of water) assesses peak inspiratory flow (PIF), where the goal was to empty the glass using the pitaco. This variable was called inspiratory IBI (I-IBI). The three reproductive measures obtained in both minigames differed by less than $10 \%$, and the highest value was used for statistical analysis.

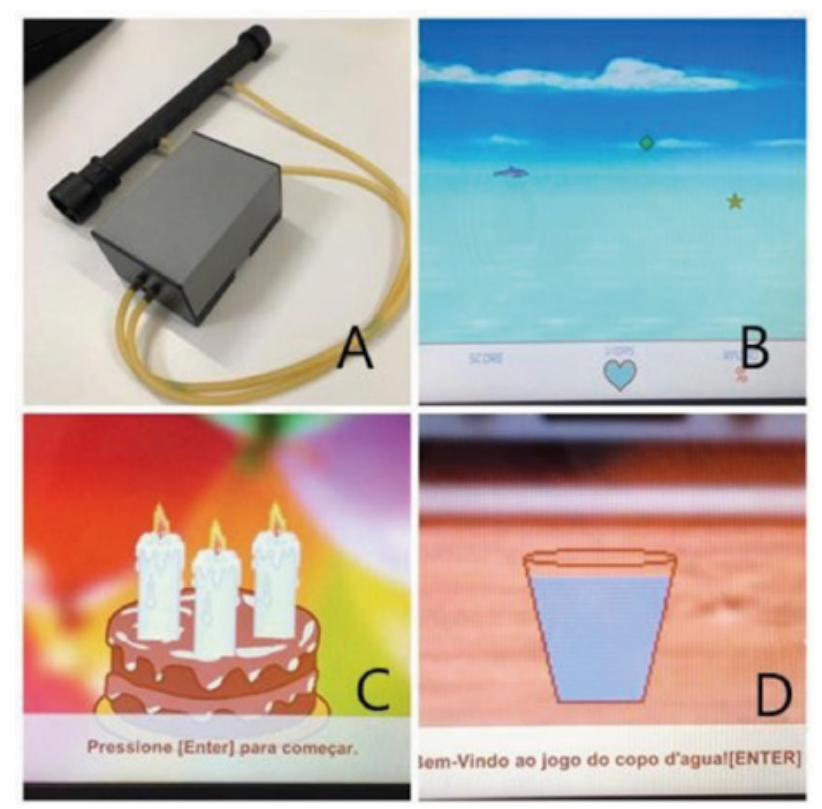

Figure 1 - IBI biomedical system.

Note: A: IBI system; B: IBI game; C: "Cake" minigame; D: "Glass of water" minigame. Source: the author (2019).

\section{Peak Flow}

The peak flow meter $\left(\operatorname{ASSES}^{\circledR}\right.$ ) was used as gold standard to assess PEF and subsequent comparison with E-IBI. With subjects sitting and wearing a nose clip, they performed a rapid forced expiration for two seconds, with one minute between measurements, until three readings with less than $10 \%$ difference between them were obtained, the highest of which was used [20]. These values were compared with their predicted counterparts, in accordance with the equation developed by Leiner et al. [21]: men: [3.95 (0.0151 x age)] x height; women: [2.93 - (0.0072 x age)] $\mathrm{x}$ height. Disposable mouthpieces were used for the measurements to maintain proper hygiene during the procedures.

\section{Manovacuometer}

Respiratory muscle strength was assessed by maximum inspiratory pressure (MIP) and maximum expiratory pressure (MEP) using a SUPORTE INDÚSTRIA BRASILEIRA manovacuometer (scaling from $120 \mathrm{CmH} 20$ ), conducted with participants sitting and wearing a nose clip. These maneuvers could be repeated up to five times, until obtaining three values with a difference of less than $10 \%$ between them, as recommended by the Brazilian Society of Pulmonology and Phthisiology [22]. MIP (Mueller's maneuver) was determined with the subject exhaling until reaching residual volume (RV) and then inhaling rapidly and forcefully. For MEP measurement (Valsalva's maneuver), the individual inhaled fully, followed by maximum forced expiration. Verbal encouragement was given during both maneuvers and measures in which the last value was higher than the first were disregarded. There was a 1-minute interval between procedures and the highest value was selected for analysis [23 - 25]. The values were then compared with their predicted counterparts, according to the equation proposed by Neder et al. [26]: men: MIP (cmH2O) $=155.3-0.80$ (age) and MEP $(\mathrm{cmH} 20)=165.3-0.81$ (age); women: MIP $(\mathrm{cmH} 20)=110.4-0.49($ age $)$ and MEP $(\mathrm{cmH} 20)=$ $115.6-0.61$ (age).

\section{Results}

After the screening of 40 participants, the eligible population was composed of 25 individuals with poststroke hemiparesis who met the inclusion criteria.

The sample consisted of 13 participants in the acute and 12 in the chronic phase. Descriptive correlational statistics were conducted disregarding lesion time, given the sample heterogeneity. The descriptive statistical data obtained are described below, characterizing the sample (Table 1). 
Table 1 - Descriptive statistics

\begin{tabular}{lccc}
\hline Variable ( $\mathbf{n}=\mathbf{2 5})$ & Mean/SD & Minimum & Maximum \\
\hline Age (years) & $61.4 \pm 13.1$ & 31 & 85 \\
T Stroke (month) & $10.7 \pm 11.9$ & 1 & 36 \\
BMI Kg/cm² & $28.2 \pm 5.28$ & 17.8 & 39 \\
BI (points) & $82.4 \pm 13.4$ & 55 & 100 \\
MMSE (points) & $23.8 \pm 4.35$ & 15 & 31 \\
PEF (L/min) & $291.8 \pm 98$ & 150 & 470 \\
MIP (cm H²) & $-53.5 \pm 28.0$ & -15 & -115 \\
MEP (cm H20) & $59.4 \pm 25.6$ & 20 & 120 \\
I-IBI (L/min) & $-101.6 \pm 35.4$ & -39.7 & -168.3 \\
E-IBI (L/min) & $167.5 \pm 45.5$ & 100.9 & 295.0 \\
\hline
\end{tabular}

Note: time since stroke in months (T Stroke); body mass index (BMI); Barthel's index (BI); Mini-Mental State Examination (MMSE); peak expiratory flow I/min (PEF); maximum inspiratory pressure in $\mathrm{cmH} 20$ (MIP); maximum expiratory pressure in $\mathrm{cmH} 20$ (MEP), IBI expiratory peak (E-IBI); IBI inspiratory peak (I-IBI); standard deviation (SD); n: total sample.

Pulmonary function was assessed using the peak flow meter and E-IBI to measure PEF and the manovacuometer to determine MIP and MEP. In order to analyze the values obtained and characterize the pulmonary function of the individuals assessed, the measured values were compared with their reference counterparts for a healthy population (Table 2).

Table 2 - Comparison between peak flow, E-IBI, MIP, MEP values obtained and predicted

\begin{tabular}{lcccc}
\hline Variables $(\mathbf{n}=\mathbf{2 5})$ & Value obtained $(\mathrm{mean} / \mathrm{SD})$ & Value predicted $(\mathrm{mean} / \mathrm{SD})$ & Percent of predicted & $\mathbf{p}$ \\
\hline PEF $(\mathrm{/} / \mathrm{min})$ & $291.8 \pm 98$ & $431.6 \pm 73.6$ & 66.6 & $<0.001$ \\
E-IBI (L/min) & $167.5 \pm 45.5$ & $431.6 \pm 73.6$ & 39 & $<0.001$ \\
MIP (cmH20) & $-53.6 \pm 28.0$ & $-90.4 \pm 18.3$ & 58.7 & $<0.001$ \\
MEP $(\mathrm{cmH} 20)$ & $58.4 \pm 25.6$ & $95.9 \pm 31.2$ & 62.9 & $<0.001$ \\
\hline
\end{tabular}

Note: Significance level $p<0.05$; $p$ : probability of the significance obtained by the t-test for independent samples; standard deviation (SD); peak expiratory flow (PEF); expiratory IBI (E-IBI); maximum inspiratory pressure (MIP); maximum expiratory pressure (MEP); n: total sample.

The results showed a significant difference in relation to the values obtained and predicted in the project, namely, $66.6 \%$ peak flow; $58.7 \%$ MIP; $62.9 \%$ MEP, showing significantly lower than expected values.

The PEF values obtained by IBI (E-IBI) using the "cake" minigame were also lower than predicted values and those obtained with the peak flow meter.

The data obtained were also analyzed for a possible correlation with the minigames of the IBI biomedical system. The correlation coefficients (r) were obtained using Pearson's test (Table 3).

Table 3 - Correlation coefficients between the IBI SG and the other tests

\begin{tabular}{lccccc}
\hline & E-IBI & I-IBI & PEF & MIP & MEP \\
\hline E-|B| & - & $-0.67^{\star}$ & $0.73^{\star}$ & $-0.43^{*}$ & $0.55^{\star}$ \\
$|-| B \mid$ & $-0.67^{*}$ & - & $-0.74^{*}$ & $0.64^{*}$ & $-0.44^{*}$
\end{tabular}

Note: IBI inspiratory peak (I-IBI); IBI expiratory peak (E-IBI); peak expiratory flow (PEF); maximum inspiratory pressure (MIP); maximum expiratory pressure (MEP); ${ }^{*} p<0.05$. 
The IBI SG shows a strong correlation with peak plow and moderate correlation with the other measures. Given the unprecedented use of PIF in the "glass of water" minigame (I-IBI) as a measure of pulmonary function and the nonexistence of a clinical interpretation of these findings, an attempt was made to establish an association between this variable (using simple regression) and MIP, considering the strong correlation obtained in the results ( $\mathrm{r}=0.64)$. The relationship between MIP and PIF obtained in regression analysis resulted in the following predictive equation: $\mathrm{MIP}=5.33$ $+0.4719 \times$ I-IBI $\left(\mathrm{r}^{2}=0.40 ; \mathrm{p}<0.001\right)$.

\section{Discussion}

The results obtained in the present study demonstrate compromised respiratory muscle strength, expressed by the decline in MIP and MEP values when compared to those predicted for the Brazilian population, according to the equation developed by Neder et al. [26], suggesting compromised pulmonary function in the patients studied here.

The lower PEF values obtained using the peak flow meter and IBI system (E-IBI) and the strong correlation found between the variables confirm the possible metric properties in assessing the capacity of individuals to generate airflow. In addition to being an assessment measure, it is also an indicator of respiratory muscle performance, since muscle strength is essential in generating adequate airflow $[27,28]$. This variable also displayed lower values when compared to their normal counterparts, according to the equation proposed by Leiner et al. [21]. It is important to underscore that the measures in the system also exhibited significant moderate correlation coefficients in relation to respiratory pressures determined by the manovacuometry.

Similar findings were reported by other authors, such as Meneghetti et al. [13], who found a decrease in MIP and MEP in a group of 22 post-stroke patients aged between 30 and 87 years. Teixeira-Salmela et al. [29] also obtained similar findings, comparing an experimental group of 16 patients with chronic stroke against a control group of 19 healthy individuals.

Zaleski et al. [30] assessed sixpatients with time since stroke between nine months and five years and found that $16.7 \%$ of the sample obtained lower than predicted values for PEF. Similar findings were reported by Roberts and Mapel [31], who underscored that patients with chronic diseases such as neurological cases exhibit $\mathrm{PEF}<80 \%$ of predicted, which is close to the values found in the present study.

The difference between PEF obtained by IBI (E-IBI) and the peak flow meter may be due to the different methods used to measure airflow, with peak flow determined by changes in volume and E-IBI by a drop in pressure, according to Poiseuille's law, since different instruments may produce inaccurate results [20].

With respect to the relation between I-IBI and E-IBI and manovacuometry (MIP and MEP), Sartor et al. [32] observed a correlation between the PEF of cough and manovacuometry, showing that individuals exhibit compromised cough and muscle function after stroke. PEF and MEP are reliable measures to analyze pulmonary function, and directly related to peak cough flow (PCF) and the ability to remove secretions from the respiratory tract [28]. This correlation was also found in the present study between E-IBI and MEP ( $\mathrm{r}=0.55)$, considering that the values obtained by the "cake" minigame also correspond to PEF.

There are no clinical associations between PIF and MIP in the literature. The strong correlation between I-IBI and MIP in the present study can be partially explained by the coefficient of determination ( $\mathrm{r} 2=0.40$ ), suggesting that PIF depends on $40 \%$ of the capacity to generate static inspiratory pressure (MIP). The IBI system reads I-IBI via a differential pressure transducer, where inspiratory flow is measured based on the drop in pressure throughout the system, based on Poiseuille's law [20]. The correlation between these variables and the regression equation may be a way to estimate MIP using the measures obtained in the minigame.

It is important that researchers and physiotherapists be willing to test new therapeutic strategies and the potential of technology should not be ignored indeed, it seems that the Serious Game (SG) is a promising tool for modern physiotherapy [33].

A number of limitations were detected in the biomedical system under study, such as the visual feedback provided by minigames, small number of patients, lack of a control group and short data collection period. Thus, further studies on this system are needed with a view to differentiating between degree of impairment and time since stroke. Thus, the IBI SG is an innovation with numerous adjustment possibilities; we believe that improvements in visual feedback and calibration of the pitaco could make the system more accurate. 


\section{Conclusion}

The IBI biomedical system used in this study showed a moderate to strong correlation with the clinical variables of pulmonary function studied and was sensitive to variations in airflow and the capacity to generate maximum respiratory pressures. Despite underestimating the peak expiratory flow obtained by the peak flow meter and not being appropriate for diagnosing airflow measures below predictive clinical values, it is an important resource for prescribing intensity and controlling progression in pulmonary rehabilitation. As such, it is a potential instrument to measure airflow in patients with post-stroke hemiparesis.

\section{References}

1. Placeres AF, Bianchin MA. Familial and socio-economic changes of patients with hemiparesis stemming from stroke. Acta Fisiatr. 2015;22(1):5-8

2. Lundy-Ekman L. Neurociência: fundamentos para a reabilitação. $3^{\text {rd }}$ ed. Rio de Janeiro: Elsevier; 2008.

3. Pereira T, Silva J, Teixeira S, Orsini M, Bastos V. Avaliação do perfil dos fatores de risco para Acidente Vascular Cerebral: estudo observacional. Rev Pesqui Fisioter. 2019;9(1):37-44.

4. Oliveira AR, Araujo T, Costa A, Morais H, Silvia V, Lopes M. Evaluation of patients with stroke monitored by home care programs. Rev Esc Enferm USP. 2013;47(5):1143-9.

5. Machado A, Silva N, Diniz G, Pessoa B, Scalzo P. Respiratory function and functional capacity in chronic stroke patients. Fisioter Mov. 2016; 29(1):95-102.

6. Béjot Y, Daubail B, Giroud M. Epidemiology of stroke and transient ischemic attacks: Current knowledge and perspectives. Rev Neurol (Paris). 2016;172(1):59-68.

7. Schuster R. Correlação entre Disfunções Motoras e Respiratórias no AVC. Rev Neuroc. 2011;19(4):587-8.

8. Song C, Joo S, Shin D. The Effects of Game-Based Breathing Exercise on Pulmonary Function in Stroke Patients: A Preliminary Study. Med Sci Monit. 2015;21:1806-11.
9. Pollock A, Baer G, Campbell P, Choo P, Forster A, Morris $\mathrm{J}$, et al. Physical rehabilitation approaches for the recovery of function and mobility following stroke. Cochrane Database Syst Rev. 2014;2014(4):CD001920.

10. Lima I, Ferreira G, Campos T, Fregonezi G. Efeito agudo da espirometria de incentivo sobre os volumes pulmonares em indivíduos hemiparéticos. Conscientiae Saude. 2011;10(4):635-42.

11. Lee D, Kim S. The effect of respiratory exercise on trunk control, pulmonary function, and trunk muscle activity in chronic stroke patients. J Phys Ther. 2018;30(5):700-3.

12. Kim N. Correlation between grip strength and pulmonary function and respiratory muscle strength in stroke patients over 50 years of age. J Exerc Rehabil. 2018;14(6):1017-23.

13. Meneghetti C, Figueiredo V, Guedes C, Batistela A. Avaliação da força muscular respiratória em indivíduos acometidos por acidente vascular cerebral. Rev Neurocienc. 2011;19(1):56-60.

14. Ocko R, Costa M. Respiratory Changes in Patients with Stroke. Biomed Biopharm Res. 2014;11(2):141-50.

15. Kulnik S, Birring S, Moxham J, Rafferty G, Kalra L. Does Respiratory Muscle Training Improve Cough Flow in Acute Stroke? Pilot Randomized Controlled Trial. Stroke. 2015;46(2):447-53.

16. Lange B, Flynn S, Chang C, Rizzo A, Bolas M. "Breathe: a game to motivate the adherence of breathing exercises". J Phys Ther Educ. 2011;25(1):30-5.

17. Nikkila S, Patel G, Sundaram H, Kelliher A, Sabharwal A. Wind runners: designing a game to encourage medical adherence for children with asthma. Proceedings of the 12th Conference on Human Factors in Computing Systems; 2012 May 5-10; Austin, TX, USA. New York, NY, USA: ACM Proceedings; 2012. p. 2411-6.

18. Joo S, Lee K, Song C. A Comparative Study of smartphone game with spirometry for pulmonary function assessment in stroke patients. Biomed Res Int. 2018;2018:2439312.

19. Santos A, Grimes R, Hounsell M, Noveletto F, Soares A, Silva H. I Blue It: Um jogo sério para auxiliar na reabilitação respiratória. Proceedings of the SBGames; 2018 Oct 29 - Nov 1; Foz do Iguaçu, Brazil: SBGames; 2018. p. 179-88. 
20. Pereira C. Espirometria. J Bras Pneumol. 2002;28(Supl 3):1-82.

21. Leiner G, Abramowitz S, Small M, Stenby V, Lewis W. Expiratory peak flow rate. Standard values for normal subjects. Use as a clinical test of ventilatory function. Am Rev Respir Dis. 1963;88(5):644-51.

22. Diretriz para teste de função pulmonar. Jornal brasileiro de pneumologia - Sociedade Brasileira de Pneumologia e Tisologia; 2002.

23. Parreira V, França D, Zampa C, Fonseca M, Tomich G, Britto R. Pressões respiratórias máximas: Valores encontrados e preditos em indivíduos saudáveis. Rev Bras Fisioter. 2007;11(5):361-8.

24. Silva P, Chiappa G, Vieira P, Roncada C. Avaliação da função muscular ventilatória. In: Martins JA, Karsten M, Dal Corso S, organizadores. Associação Brasileira de Fisioterapia Cardiorrespiratória e Fisioterapia em Terapia Intensiva. PROFISIO Programa de Atualização em Fisioterapia Cardiovascular e Respiratória: Ciclo 2. Porto Alegre: Artmed Panamericana; 2016. p. 9-46.

25. Pessoa I, Houri Neto M, Montemezzo D, Silva L, Andrade A, Parreira V. Predictive equations for respiratory muscle strength according to international and Brazilian guidelines. Braz J Phys Ther. 2014;18(5):410-8.

26. Neder J, Andreoni S, Lerario M, Nery L. Reference values for lung function tests. II. Maximal respiratory pressures and voluntary ventilation. Braz J Med Biol Res. 1999;32(6):719-27.
27. Nagato A, Nunes L, Dourado V, Diniz M, Silva M, Dornelas G, et al. Correlação entre a pressão expiratória máxima (PEmáx.) e pico de fluxo expiratório máximo (PFE) em indivíduos saudáveis. Rev Interdisciplin Estud Exp Anim Hum. 2012;4:7-15.

28. Jo M, Kim N. The correlation of respiratory muscle strength and cough capacity in stroke patients. J Phys Ther Sci. 2016;28(10):2803-5.

29. Teixeira-Salmela L, Parreira V, Britto R, Brant T, Inácio E, Alcântara T, et al. Respiratory pressures and thoracoabdominal motion in community dwelling chronic stroke survivors. Arch Phys Med Rehabil. 2005;86(10):1974-8.

30. Zaleski T, Camera F, Wisniewski E, Wisniewski M. Avaliação da força muscular respiratória e função pulmonar em indivíduos com acidente vascular cerebral. Rev Perspect. 2018;42:15-22.

31. Roberts M, Mapel D. Limited Lung Function: Impact of Reduced Peak Expiratory Flow on Health Status, HealthCare Utilization, and Expected Survival in OlderAdults. Am J Epidemiol. 2012;176(2):127-34.

32. Sartor M, Guillen-Solà A, Ramirez-Fuentes C, Duarte E, Marco E. Peak expiratory cough flow and respiratory muscle function in acute stroke patients. Eur Respir J. 2017;50(suppl 61):1-5.

33. Soares A, Woellner S, Andrade C, Mesadri T, Bruckheimer A, Hounsell M. The use of Virtual Reality for upper limb rehabilitation of hemiparetic Stroke patients. Fisioter Mov. 2014;27(3):309-17.

Received: 12/17/2019

Recebido: 17/12/2019

Approved: 03/31/2020

Aprovado: 31/03/2020 